\title{
The extensive intergenerational molecular effects of ocean acidification on the olfactory epithelium transcriptome of a marine fish are associated with a better viral resistance
}

\section{Mishal Cohen-Rengifo ( $\sim$ mishal.cohen.r@gmail.com )}

IFREMER, PFOM-ARN

Morgane Danion

Technopôle Brest-Iroise

Anne-Alicia Gonzalez

MGX, Biocampus Montpellier, CNRS, INSERM, University of Montpellier

Marie-Laure Bégout

MARBEC, University of Montpellier, CNRS, IFREMER, IRD

Lauriane Madec

IFREMER, PFOM-ARN

Alexandre Cormier

IFREMER, SEBIMER

Cyril Noël

IFREMER, SEBIMER

Joëlle Cabon

Technopôle Brest-Iroise

Thomas Vitré

IFREMER, PFOM-ARN

Felix C. Mark

Alfred Wegener Institute Helmholtz Centre for Polar and Marine Research (AWI)

David Mazurais

IFREMER, PFOM-ARN

\section{Research Article}

Keywords: anti-viral immunity, betanodavirus, climate change, European sea bass, intergenerational ocean acidification, metabolism, neuro-sensory system, olfactory epithelium, transcriptomics

Posted Date: December 29th, 2021 
DOI: https://doi.org/10.21203/rs.3.rs-1197163/v1

License: (c) (1) This work is licensed under a Creative Commons Attribution 4.0 International License. Read Full License 


\section{Abstract \\ Background}

Progressive climate-induced ocean acidification (OA) impacts marine life in ways that are difficult to predict but are likely to become exacerbated over generations. Although marine fishes can balance internal acid-base homeostasis efficiently, indirect ionic regulation effects that alter neurosensory systems can result in behavioural abnormalities. In marine invertebrates, OA can also affect immune system function, but whether this is the case in marine fishes of ecological and commercial importance is not yet understood. Farmed fish are highly susceptible to disease outbreak yet strategies for overcoming such threats in the wake of $\mathrm{OA}$ are wanting. Here, we exposed two generations of the European sea bass (Dicentrarchus labrax) to end-of-century predicted $\mathrm{CO}_{2}$ levels (IPCC RCP8.5), with parents being exposed for four years and their offspring for two years. Our design included a transcriptomic analysis of the olfactory rosette (collected from the F1 offspring) and a viral challenge (exposing F1 offspring to betanodavirus) where we assessed survival rates.

\section{Results}

We discovered long-term intergenerational molecular trade-offs in both sensory and immune systems. Specifically, RNA-Seq analysis of the olfactory rosette, the peripheral olfactory organ, from two-year-old F1 offspring revealed extensive regulation in genes involved in ion transport and neuronal signalling, including GABAergic signalling. We also detected extensive OA-induced intergenerational up-regulation of genes associated with odour transduction, synaptic plasticity, neuron excitability and wiring and downregulation of genes involved in energy metabolism. In addition, intergenerational exposure to $O A$ induced up-regulation of genes involved in innate antiviral immunity (pathogen recognition receptors and interferon-stimulated genes) in combination with down-regulation of the protein biosynthetic machinery. Consistently, OA-exposed F1 fish challenged with betanodavirus, which causes damage to the nervous system of marine fish, had acquired improved resistance.

\section{Conclusion}

F1 exposed to OA-intergenerational acclimation showed superior viral resistance, though as their metabolic and odour transduction programs were altered, odour-mediated behaviours might be consequently altered. Our results reveal that trade-offs in adaptive plastic responses is a core feature of the olfactory epithelium transcriptome in OA-exposed fish, suggesting that intergenerational plasticity propagate with progressive exposure to $\mathrm{OA}$ and will have important consequences for how cultured and wild fish interacts with its environment.

\section{Background}


Atmospheric $\mathrm{CO}_{2}$ concentration has increased from preindustrial levels of $280 \mathrm{ppm}$ to the current value of 414 ppm (Dlugokencky and Tans 2021), and is expected to reach 1 000 ppm by the end of this century (Caldeira and Wickett 2003; IPCC 2014; Bindoff et al. 2019). These changes in turn lead to ocean acidification $(\mathrm{OA})$, including changes in the carbonate system equilibrium such as reduced carbonate ion concentrations and $\mathrm{pH}$. According to the future warming scenario RCP 8.5, seawater $\mathrm{pH}$ will decrease by 0.3-0.4 units by 2100 in the North Atlantic Ocean (Caldeira and Wickett 2003; Orr et al. 2005; IPCC 2014).

$\mathrm{OA}$ alone or coupled with ocean warming poses global-scale threats to marine life ranging from the invisible scale of microbes to ecosystem levels (Danovaro et al. 2011; Hassenrück et al. 2016; Hutchins and Fu 2017; Cavicchioli et al. 2019). Given their efficient capacity for maintaining acid-base homeostasis, fishes have long been considered to be robust organisms capable of tolerating OA (Claiborne et al. 1999; Claiborne et al. 2002; Heuer and Grosell 2014; Esbaugh 2017). However, reported indirect impacts of OA include both inter- and intra-specific changes in sensory behaviours (Clements and Hunt 2015), which result from directly altered neurosensory systems (Munday et al. 2009; Dixson et al. 2010; Chung et al. 2014; Hamilton et al. 2014; Rossi et al. 2016; Ashur et al. 2017; Tresguerres and Hamilton 2017; Holmberg et al. 2019; Paula et al. 2019). Ultimately, these affect reproduction, fitness and mortality (Nilsson et al. 2012; Chivers et al. 2014; Faria et al. 2018; Servili et al. 2020). Although such effects are complex and vary with both biological traits and methods employed (Williamson et al. 2020), sensory behavioural alterations induced by acid-base regulation are generally explained as a GABAergic system dysfunction due to an inversion of the $\mathrm{Cl}^{-} / \mathrm{HCO}_{3}{ }^{-}$channels across neuronal membranes (Nilsson et al. 2012; Schunter et al. 2019). However, molecular and electrophysiological approaches also suggest that changes in calcium homeostasis and decrease in synaptic plasticity underlie OA impacts on synaptic activity in the olfactory bulb (Porteus et al. 2018). The capacity of the fish neurosensory system to cope with OA depends on the species considered and the parental phenotype (Lai et al. 2017; Tsang et al. 2020). In addition, OA-induced effects can vary over multiple generations (Miller et al. 2012; Munday 2014), as observed in Atlantic cod where parental acclimation to OA increased survival of offspring under elevated $\mathrm{CO}_{2}$ (Stiasny et al. 2016). Whether such intergenerational acclimation is correlated with increased offspring viability in other economically exploited species is an open question.

Relative to the well-recognized influence of ocean warming on the emergence of pathogenic species and spread of viral diseases (Vezzulli et al. 2013; Cavicchioli et al. 2019), the influence of OA has received less attention, although it is known that virus abundance and virus-host interactions are altered by OA (Liu et al. 2010; Traving et al. 2014; Tangherlini et al. 2021). Even though the environment influences disease spread, it can also modulate the host immune responses to mitigate infection. Understanding how the environment, namely $\mathrm{OA}$, influences the host immune system, and more specifically the sensitivity to pathogens, will become critical for predicting future changes in both population dynamics and aquaculture.

Earlier studies reported that OA can alter immune system parameters in marine invertebrates (Bibby et al. 2008; Mackenzie et al. 2014; Wang et al. 2016; Leite Figueiredo et al. 2016; Sun et al. 2017; Castillo et al. 2017; Migliaccio et al. 2019; Wang et al. 2021). Much less is known in marine fishes (Bresolin De Souza 
et al. 2014; Bresolin de Souza et al. 2016), and especially species of ecological and commercial importance, such as the European sea bass (Dicentrarchus labrax). Recently, the $c b / n 11$ gene, which is involved in the pathogen defence, was reported to be up-regulated in the olfactory rosette of two successive generations of $D$. labrax exposed to $O A$, suggesting that $\mathrm{OA}$ can induce immune system changes (Mazurais et al. 2020). As the olfactory epithelium is in constant contact with seawater, it functions as a gateway for invading pathogens (Mori et al. 2005) and is capable of eliciting a strong antiviral response (Tacchi et al. 2014; Sepahi et al. 2019). However, although a transcriptomic analysis of the olfactory bulb of $D$. labrax after seven days of exposure to OA within a generation detected significant expressions changes in genes involved in synaptic development, growth and ion transport, genes involved in the immune system were not significantly altered (Porteus et al. 2018).

Here, we reasoned that longer-term exposure to OA would serve as a proxy for $D$. labrax adaptations to $\mathrm{OA}$, and that a transcriptome analysis of the olfactory epithelium from $\mathrm{F} 1$ generation offspring would help us understand, at a molecular level, how fish adapt over several years and across generations. We also asked how such OA-induced adaptations impacted on pathogen susceptibility by conducting an experimental betanodavirus challenge. Betanodavirus infections in $D$. labrax occur with high frequency at every life stage in aquaculture facilities (Le Breton et al. 1997; Munday et al. 2002) and causes viral nervous necrosis (VNN) by infecting the brain and retina, resulting in mass mortality and a range of neurological and behavioural abnormalities (Breuil et al. 1991; Le Breton et al. 1997; Munday et al. 2002; Costa and Thompson 2016). As betanodavirus can infect more than 120 species of marine and freshwater fishes as well as invertebrates (Bandín and Souto 2020), an outbreak represents a significant risk for breeding, rearing, and harvesting of fish in all types of water environments.

\section{Results}

Here, we designed a long-term experimental paradigm in which parental Dicentrarchus labrax (the F0 generation), were reared in the same $\mathrm{pH}$ conditions as their offspring (the $\mathrm{F} 1$ generation) (control treatment $\mathrm{pH} 8.0, \mathrm{pCO}_{2}=590 \mu \mathrm{atm}$ or $\mathrm{OA}$ treatment $\mathrm{pH} 7.6, \mathrm{pCO}_{2}=1520 \mu \mathrm{atm}$, as predicted by 2100 in the IPCC RCP8.5 scenario). To generate the F1 generation, and as previously described, we collected gametes from 4-year-old F0 fish that had been reared from larval stage to adulthood in control or OA conditions (Crespel et al., 2017; Cominassi et al., 2019, 2020; Howald et al., 2019; Mazurais et al., 2020). For each pH treatment, we collected and pooled sperm and eggs from 20 males and 6 females (see methodological summary in figure 1). We then performed in vitro fertilization, after which the resulting F1 generation was returned to OA or control conditions (Crespel et al. 2017; Cominassi et al. 2019; Howald et al. 2019; Cominassi et al. 2020; Mazurais et al. 2020) (figure 1). After 2 years, we split our experimental F1 cohorts into two experimental arms; one in which we performed gene expression profiling of olfactory rosette tissue from $\mathrm{F} 1$ juveniles (7 each from control and OA rearing conditions, figure 1 ), and a second arm in which we conducted a betanodavirus challenge, as previously described, to investigate how long-term $\mathrm{OA}$ conditions impact on viral infection parameters in D. labrax (figure 1). 


\section{Viral challenge}

In non-infected fish, and as expected, we did not detect any mortality, clinical symptoms or lesions. However, in infected fish, symptoms of VNN disease i.e. darkening of the body, whirling swimming and hyperactivity, were evident after five days in the control treatment (dpi 5, pH8.0) but appeared three days later in fish exposed to the OA treatment (dpi 8, pH7.6). Similarly, mortality on-set was staggered such that fish started dying at $7 \mathrm{dpi}$ in the control treatment and at $9 \mathrm{dpi}$ in the $\mathrm{OA}$ treatment), but after 25 days, no additional mortality was observed (figure 2). When we performed a Kruskal-Wallis test together with a Dunn's post hoc test to determine the Mean Day to Death (MDD), we found this to be $10.7 \mathrm{dpi}$ in control and $12.8 \mathrm{dpi}$ in OA sea water conditions. At the peak of mortality, the presence of the virus in the pool of organs was indistinguishable between treatments. At the end of the challenge, more fish survived infection in $\mathrm{OA}$ relative to control conditions, as reflected by a significantly higher survival rate (KruskalWallis, $\mathrm{H}=3.84$, $\mathrm{p}$-value $=0.05$ in $\mathrm{OA}$ treatment $(68 \%)$ than in the control $(38 \%)$ (figure 2$)$.

\section{Global gene expression profiling}

After a 24h fasting period, we dissected out the olfactory rosette from F1 juveniles (7 each, reared for 2 years in either OA and control conditions), extracted RNA and verified RNA integrity as described in Materials and Methods. cDNA library construction for the 14 samples and RNA-sequencing was performed by the GenomiX sequencing platform (MGX, Montpellier, France). Across the 14 libraries, Illumina sequencing generated a total of 772449468 reads with an average of 55450000 reads per library. More than $90 \%$ of the sequencing reads for each library (except for one sample that was $72 \%$ ) could be mapped to $D$. labrax reference genome. Of the total 26721 transcripts, 9112 were differentially expressed (with an adjusted p-value $\leq 0.01$ ), with 4515 (49.6\%) up-regulated and 4598 (50.4\%) downregulated in the OA-exposed cohort (listed in additional file 2). To validate the RNA-Seq results, we performed qPCR analysis of the samhd1, gvinp1, t/r3, cxcl14 and nfat5 genes through which we obtained robust coefficient of correlation metrics $\left(r_{\text {samhd }}: 0.90, r_{\text {gvinp } 7}: 0.74, r_{t / r 3}: 0.91, r_{c x c 174}: 0.91\right.$ and $\left.r_{\text {nfat5 }}: 0.89\right)$.

\section{Regulation of pH, bicarbonate transport and chloride homeostasis}

Overall, we found that genes involved in regulation of $\mathrm{pH}$, bicarbonate transport and chloride homeostasis were significantly differentially expressed (Table 1 , additional file 3 ). Among the genes involved in $\mathrm{pH}$ regulation, members of the slc9a family genes were either up-regulated (s/c9a1, s/c9a7) or down-regulated (s/c9a2, s/c9a9) in OA-reared $\mathrm{F} 1$ juveniles whereas genes involved in bicarbonate transport, all slc4a family members, were up-regulated. 27 chloride transport-associated gene transcripts were up-regulated by OA exposure, of which the majority (22 transcripts) included Slc12a family genes (K$\mathrm{Cl}$ cotransporters) and GABA receptors. 
Table 1

Genes involved in the regulation of $\mathrm{pH}$, bicarbonate transport and chloride transport regulated $(\mathrm{p}$ value $\leq 0.01$ ) by ocean acidification in the olfactory rosette of F1 European Sea Bass (Dicentrarchus labrax) juveniles. Several transcripts may originate from the same gene. GO: Gene Ontology.

\begin{tabular}{|llll|}
\hline Go term & $\begin{array}{l}\text { Regulation } \\
\text { by OA }\end{array}$ & $\begin{array}{l}\text { Number of } \\
\text { transcripts }\end{array}$ & Regulated genes \\
\hline $\begin{array}{l}\text { Regulation } \\
\text { of pH }\end{array}$ & Up & 3 & slc4a10, slc9a1, slc9a7 \\
\hline $\begin{array}{l}\text { Bicarbonate } \\
\text { transport }\end{array}$ & Up & 3 & slc4a7, slc4a8, slc4a10 \\
\hline $\begin{array}{l}\text { Chloride } \\
\text { homeostasis }\end{array}$ & Up & 22 & $\begin{array}{l}\text { ano1, ano3, ano5, ano8, cftr, clcn2, clcn6, clcn7, clic4, } \\
\text { clic5, gabra2, gabra4, gabrg2, gabrr2, glrb, slc4a10, } \\
\text { slc12a2, slc12a4, slc12a5, slc12a7, slc12a10 }\end{array}$ \\
\hline & Down & 5 & \begin{tabular}{l} 
abcc4, clcn5, fam131a, icln \\
\hline
\end{tabular}
\end{tabular}

\section{Neuronal plasticity and activity}

As predicted from an expression analysis of olfactory epithelium, GO analysis identified enrichment of up-regulated genes related to neuronal cell structures in OA-treated tissue (e.g. "neuron projection", "synapse", "postsynaptic density", "voltage-gated sodium channel complex", "neuronal cell body") (additional file 4). For instance, within the 90 genes related to "neuron projection", we found axonal function associated genes such as kinesin heavy chain isoform 5c-like (kif5c), semaphorins, ephrin typeb receptor 2 (ephb2), cyclin-dependent kinase 5 (cdk5), amyloid beta a4 precursor protein-binding family b member 1-like ( $a p b b 1)$ and growth associated protein 43 (gap43) (Table 2, additional file 5). Based on biological process GO enrichment, we found that genes associated with "signal transduction" (516 transcripts), including "regulation of small GTPase mediated signal transduction" (95 transcripts) or "cell surface receptor signalling pathway" (160 transcripts), were over-represented with OA-induced upregulated genes (figure 3A, additional file 6). Among the 187 genes involved in "intracellular signal transduction", we found known neuronal plasticity pathways such as the Neurotrophin TRK receptor signalling pathway (19 transcripts), the Glutamate signalling pathway (13 transcripts) and the Ephrin signalling pathway (9 transcripts) (Table 2, additional file 7). Genes related to "regulation of synaptic plasticity" (22 transcripts) were also enriched within OA-induced up-regulated genes (figure 3A, additional file 6), and genes coding for calcium calmodulin-dependent protein kinase type ii subunit beta-like (camk2b), synaptogyrin-1 (syngr1) and neuroplastin-like (nptn) proteins exhibited significantly elevated gene expression levels (additional file 8). In addition, biological processes related to "regulation of action potential", were also over-represented in OA-treated tissue (figure 3A, additional file 6) included genes involved in potassium, sodium and calcium ion transport (e.g. scn2b, scn1a, cacna1d, kcn2, kcna5) (Table 2, additional file 9). Consistently, "regulation of neurotransmitter levels" genes were enriched within genes up-regulated by $\mathrm{OA}$, including genes involved in the GABAergic signalling pathway (up-regulated: cacna1a, gabra2, nf1, slc6a13) (Table 2, additional file 10). 
Table 2

Examples of enriched gene ontologies and associated genes involved in neural plasticity and activity that were up-regulated $(\mathrm{p} \leq 0.01)$ by ocean acidification in the olfactory rosette of F1 European Sea Bass

(Dicentrarchus labrax) juveniles. Several transcripts may originate from the same gene. This list is given an example, with no attempt to be exhaustive. See additional files 5-10 for an enlarged version that include gene description and associated GO terms. GO: Gene Ontology.

\begin{tabular}{|c|c|c|c|}
\hline GO term & Subcategory & $\begin{array}{l}\text { Number of } \\
\text { transcripts }\end{array}$ & Examples of regulated genes \\
\hline \multirow[t]{2}{*}{ Neuron projection } & Axon guidance & 15 & $\begin{array}{l}\text { apbb1, cdk5, epha5, epha8, } \\
\text { ephb2, kif5c, gap43, sptbn4, tgfb2 }\end{array}$ \\
\hline & Axon extension & 3 & cdk5, map $1 b$, sema3a \\
\hline \multirow[t]{4}{*}{$\begin{array}{l}\text { Intracellular signalling } \\
\text { transduction } \\
\text { neuroplasticity }\end{array}$} & $\begin{array}{l}\text { Neurotrophin TRK } \\
\text { receptor sig. } \\
\text { pathway }\end{array}$ & 19 & $\begin{array}{l}\text { adcy6, arhgef7, calm1, erbb4, } \\
\text { gab1, kras, ngef, shc1, vav2 }\end{array}$ \\
\hline & $\begin{array}{l}\text { Glutamate signaling } \\
\text { pathway }\end{array}$ & 13 & $\begin{array}{l}\text { gnaq, glur2b, gria1a, gria3b, } \\
\text { gria4k, grik2, grik5, grin3a, } \\
\text { grind2d }\end{array}$ \\
\hline & $\begin{array}{l}\text { Ephrin signaling } \\
\text { pathway }\end{array}$ & 9 & $\begin{array}{l}\text { chn1, efna5, ek1, epha5, epha7, } \\
\text { epha8, ephb1, ephb2, etk2 }\end{array}$ \\
\hline & $\begin{array}{l}\text { Regulation of } \\
\text { synaptic plasticity }\end{array}$ & 22 & $\begin{array}{l}\text { camk } 2 b, \text { cpl } \times 2 \text {, grik2, kcnn2, nf1, } \\
\text { nptn, shank3, syngr1 }\end{array}$ \\
\hline $\begin{array}{l}\text { Regulation of action } \\
\text { potential }\end{array}$ & & 21 & $\begin{array}{l}\text { ank2, ank3, cacna1d, kcnip } 1, \\
k c n c 2, \text { ryr2, scn } 1 a, \text { scn } 2 b\end{array}$ \\
\hline $\begin{array}{l}\text { Reg. of the } \\
\text { neurotransmitter levels }\end{array}$ & & 34 & $\begin{array}{l}\text { cacna1a, gabra2, napb, nf1, } \\
\text { rims1, slc6a13, snap25, stx1a, } \\
\text { trpm7 }\end{array}$ \\
\hline
\end{tabular}

\section{Metabolism}

GO processes enriched within down-regulated genes were primarily related to metabolism (figure 3B, additional file 11). A large number of these are implicated in biosynthetic processes ( 465 transcripts); peptide biosynthetic process (105 transcripts), regulation of translation (43 transcripts), carbohydrate derivative biosynthetic process ( 89 transcripts) and ATP biosynthetic process ( 20 transcripts) (Tables 3 , additional file 12 and 13). Other down-regulated biological processes included oxidation-reduction process (266 transcripts), catabolic process (184 transcripts), cell division (62 transcripts) and viral process (16 transcripts) (figure 3B, additional file 14). Consistently, down-regulated gene programs included the ribonucleoprotein complex (166 transcripts), the mitochondria (217 transcripts) - including the mitochondrial respiratory chain complex I (12 transcripts), the mitochondrial matrix (29 transcripts), the catalytic complex (228 transcripts) and the oxidoreductase complex (29 transcripts) (additional file 15). 
Table 3

Examples of enriched gene ontologies and associated genes related to metabolism, viral process and cell division that were down-regulated ( $p$-value $\leq 0.01$ ) by ocean acidification in the olfactory rosette of F1 European Sea Bass (Dicentrarchus labrax) juveniles. Several transcripts may originate from the same gene. This list is given as an example, with no attempt to be exhaustive. See additional files 12-14 for an enlarged version that include gene description and associated GO terms. GO: Gene Ontology.

\begin{tabular}{|c|c|c|c|}
\hline GO term & Subcategory & $\begin{array}{l}\text { Number of } \\
\text { transcripts }\end{array}$ & Examples of regulated genes \\
\hline $\begin{array}{l}\text { Peptide biosynthetic } \\
\text { process }\end{array}$ & & 105 & $\begin{array}{l}\text { gtf2h2, mrp/35_37, mrps10-12, } \\
\text { mrps21, noa1, ssr1, rs17, rp/18 }\end{array}$ \\
\hline \multirow[t]{3}{*}{$\begin{array}{l}\text { Carbohydrate derivative } \\
\text { biosynthetic process }\end{array}$} & $\begin{array}{l}\text { Tricarboxylic acid } \\
\text { cycle }\end{array}$ & 22 & $\begin{array}{l}\text { aco1, aco2, cs, fh, idh1-3, mdh1, } \\
\text { ogdh, pdhb, sdha-c, sucla2 }\end{array}$ \\
\hline & Gluconeogenesis & 9 & $\begin{array}{l}\text { aldoc, eno2, pck2, fpb1, pgk1, } \\
\text { slc25a11, slc25a12, smek2, tpi1a, }\end{array}$ \\
\hline & $\begin{array}{l}\text { ATP biosynthetic } \\
\text { process }\end{array}$ & 20 & $\begin{array}{l}\text { atp } 51, \text { atp } 5 b, \text { atp } 5 g 3, \text { atp5a } 1, \text { atp } 5 i, \\
\text { atp5f1, atp5g } 1 \text {, atp5o }\end{array}$ \\
\hline $\begin{array}{l}\text { Oxidation-reduction } \\
\text { process }\end{array}$ & & 266 & $\begin{array}{l}\text { aldh6a1, cyb5r3, cyb5r4, g6pd, } \\
\text { gapdh, ndufs } 1-7, \text { prdx } 1-6\end{array}$ \\
\hline \multirow[t]{2}{*}{ Catabolic process } & $\begin{array}{l}\text { Organic substance } \\
\text { catabolic process }\end{array}$ & 169 & $\begin{array}{l}\text { afg3/1p, capn3, paox, pcsk9, } \\
\text { psma6, tpp 1, usp 14, usp2a }\end{array}$ \\
\hline & $\begin{array}{l}\text { mRNA catabolic } \\
\text { process }\end{array}$ & 37 & $\begin{array}{l}\text { cnot11, ncbp1, ncbp2, pan2, pan3, } \\
\text { patt1, smg5, smg8, uba52 }\end{array}$ \\
\hline Viral process & Viral transcription & 15 & $\begin{array}{l}r / 23 a, r / 37 a, r p / 19, r p / 23, r p / 38-39 \\
r p s 25, r p s 25, r p s 27, r p s 29\end{array}$ \\
\hline Cell division & & 62 & $\begin{array}{l}\text { ccna2, ccnb1-2, ccne1-2, cdc2, } \\
\text { cdc20, cdc34, cdc40, cdk2, fzr1 }\end{array}$ \\
\hline
\end{tabular}

Finally, genes associated with AMP-activated protein kinase (AMPK) and mTOR signalling pathways, key energy-regulating pathways, were also differentially expressed between the two treatments. Specifically, mTOR signalling pathway genes ( $m$ tor, lamtor1, lamtor3, $\mathrm{m} / \mathrm{st} 8$ ) were down-regulated while two AMPK subunit genes (prkag1-2) were found up-regulated by OA (additional file 2).

\section{Innate immunity and anti-viral response}

Intergenerational exposure to $\mathrm{OA}$ induced up-regulation of a substantial number of genes involved in innate antiviral immunity, partially listed in Table 4 and more exhaustively in table additional file 16 . In particular, these belong to four classes of the germline-encoded Pattern Recognition Receptors (PRRs), which include nucleotide oligomerization and binding domain (NOD)-like receptors (NLRs), C-type lectin receptors (CLRs), toll-like receptors (TLR) and a retinoic acid inducible gene--like receptor (RLRs). Indeed, NLRs were the most represented PRRs with 109 transcripts, including three encoding protein nlrc3-like variants for which expression levels were elevated more than 30-fold (in additional file 16 and 17, see transcript IDs: DLAgn_00244700, DLAgn_00265820 and DLAgn_00234590). Other up-regulated genes 
included the melanoma differentiation-associated gene 5 (mda5 or ifih1) and Interferon-Stimulated Genes (ISG), which included GTPase-Immune-Associated Nucleotide-Binding Proteins (36 genes including gimap4, gimap7 and gimap8), interferon-induced very large GTPase 1 (gvinp1) and GTP binding protein $\mathrm{Mx}(m x)$. Other up-regulated ISG transcripts included interferon-induced proteins with tetratricopeptide repeats (ifit2), MHC class I proteins, members of the TRIM protein family (trim25), an IFN-induced doublestranded RNA-activated protein kinase ( $p k r 1$, prkrir), the grass carp haemorrhagic virus (GCHV)-induced gene -1 (gig1), the nuclear autoantigen sp-100 (sp100), the sterile alpha motif and histidine/aspartic acid domain-containing protein 1 (samhd1), two apolipoproteins (apo1,3), a damage regulated autophagy modulator protein (dram1) and three caspases (casp 1, casp 6 and casp 7 ). In addition, a small number of genes within the ISG category were also significantly down-regulated in the OA condition such as gig2 or irig, trim39 and trim8. While some transcripts associated with the interferon JAK-STAT signalling pathway were also up-regulated (jak2, stat5.1, stat6), several key genes in this pathway were downregulated, such as mitochondrial antiviral signalling (mavs), myeloid differentiation factor 88 (myd88), tnf receptor-associated factor 3 (traf3) and several interferon regulatory factors (irf4, irf5, irf6, irf8). 
Table 4

Categories and number of transcripts related to genes involved in innate immunity and/or antiviral defence up and down-regulated ( $p$-value $\leq 0.01$ ) by ocean acidification in the olfactory rosette of F1 European Sea Bass (Dicentrarchus labrax) juveniles. PRR: germline-encoded Pattern Recognition Receptors; ISG: Interferon (INF)-stimulated Genes. Several transcripts may originate from the same gene.

This list is given as an example, with no attempt to be exhaustive. See Additional files 15-17 for an enlarged version that include gene description and associated GO terms. Nd: Not defined.

$\begin{array}{llll}\text { Category and Subcategory } & \begin{array}{l}\text { Number of } \\ \text { transcripts }\end{array} & \begin{array}{l}\text { Examples of } \\ \text { regulated genes }\end{array} & \text { Function }\end{array}$

UP-regulated

\begin{tabular}{|c|c|c|c|c|}
\hline \multirow[t]{2}{*}{ PRRs } & $\begin{array}{l}\text { NLRs: nucleotide } \\
\text { oligomerization and } \\
\text { binding domain } \\
\text { (NOD)-like receptors }\end{array}$ & 109 & $\begin{array}{l}\text { nlrc3; nlrc5; } \\
\text { nlrp 1b; nlrp4e; } \\
\text { trpm2; nod2; } \\
\text { nwd1; spry2; } \\
\text { spry3 }\end{array}$ & $\begin{array}{l}\text { pathogen recognition receptor } \\
\text { intracellular signal } \\
\text { transduction (Li et al. 2018; } \\
\text { Zhang et al. 2019) }\end{array}$ \\
\hline & $\begin{array}{l}\text { CLRs: C-type lectin } \\
\text { receptors }\end{array}$ & 8 & $\begin{array}{l}\text { illr3; cd209; } \\
\text { c209d }\end{array}$ & $\begin{array}{l}\text { pathogen recognition } \\
\text { receptor/sensing RNA viruses } \\
\text { (Yang et al. 2015) }\end{array}$ \\
\hline
\end{tabular}

$\begin{array}{llll}\text { TLRs: toll-like } & 6 & \text { t/r1/; t/r2-1; t/r21; } & \text { pathogen recognition } \\ \text { receptors } & & \text { t/r22; t/r3; t/r9 } & \text { receptor/sensing RNA }\end{array}$

receptor/sensing RNA viruses (Matsuo et al. 2008; Langevin et al. 2013; Quiniou et al. 2013)

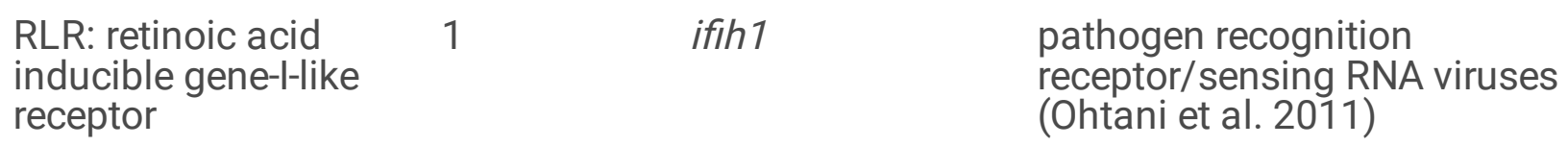

ISG GTPase- GTPase $36 \quad$ gimap7; secretion of cytokines; antirelated imap gimap4; gimap8 apoptosis of lymphocytes (Kim family family et al. 2018)

\begin{tabular}{|c|c|c|c|}
\hline $\begin{array}{l}\text { very } \\
\text { large } \\
\text { GTPase }\end{array}$ & 9 & gvinp 1 & $\begin{array}{l}\text { Host resistance (Pilla-Moffett } \\
\text { et al. 2016; Pavlovich et al. } \\
\text { 2020) }\end{array}$ \\
\hline
\end{tabular}

\begin{tabular}{|c|c|c|c|}
\hline $\begin{array}{l}\text { GTP } \\
\text { binding } \\
\text { protein } \\
\text { Mx }\end{array}$ & 1 & $m x$ & $\begin{array}{l}\text { antiviral effector; inhibition of } \\
\text { viral replication (Jensen and } \\
\text { Robertsen 2002; Haller et al. } \\
\text { 2007; Su et al. 2009; Wu et al. } \\
\text { 2010) }\end{array}$ \\
\hline
\end{tabular}

IFN-induced prot.

$1 \quad$ ifit2

with

tetratricopeptide repeats

$\begin{array}{lll}\text { MHC class I } & 13 \quad N d\end{array}$

inhibition of viral translation and replication (Fensterl et al. 2012; Fensterl and Sen 2015)

immunomodulator; antigen presentation (Koppang et al. 1999; Hansen and La Patra 2002; Robertsen 2006) 


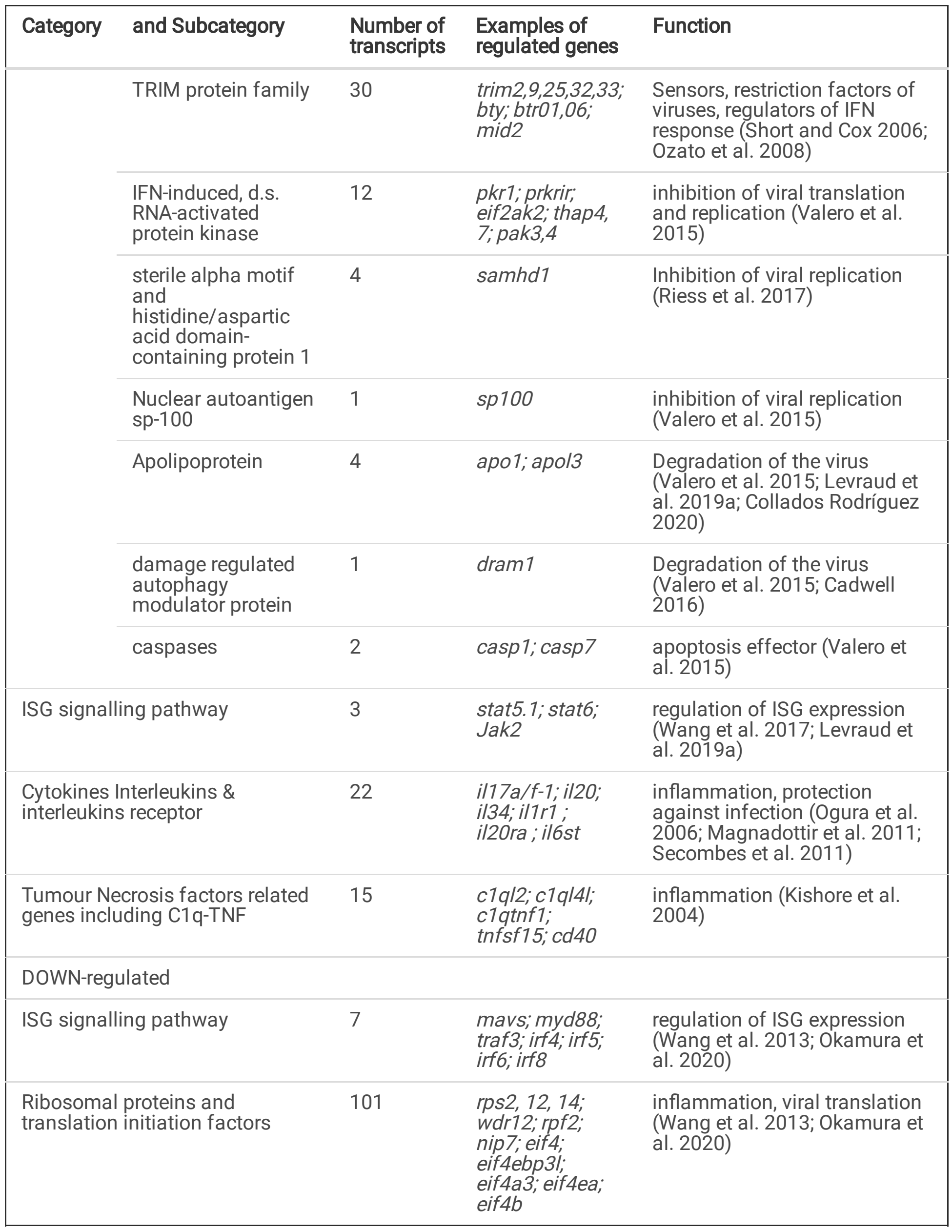


Finally, a large swath of cytokine-encoding transcripts were up-regulated, including 22 interleukinassociated genes (e.g. il34; il20; il17a/f-1; il1rl2; il6st; il20ra; il18r1; il7r; il4r) and 15 tumour necrosis factor-associated genes (tnip2; c1q/2; c1ql4l; c1qtnf1; tnfsf15; cd40) (Table 4, additional file 5). In contrast, almost 100 transcripts related to genes typically involved in viral protein translation during infection (e.g. rps2, 12, 14; wdr12; rpf2; nip7; eif4; eif4ebp3l; eif4a3; eif4ea; eif4b) were down-regulated (Table 4, additional file 5).

\section{Discussion}

Because the olfactory epithelium in fish is in direct contact with water, its cells are particularly exposed to environmental changes. However, in the context of global climate change and its longer-term impact of marine life, it's difficult to predict how fish and other species will adapt to an increasingly acidic marine environment. Indeed, impacts of olfactory systems in the context of OA were reported to impact on olfactory behaviour in broadly related work (Munday 2014; Porteus et al. 2018; Jiahuan et al. 2018; Williams et al. 2019; Porteus et al. 2021). For instance, Dicentrarchus labrax, when exposed to predicted end-of-century OA (around $1000 \mu \mathrm{atm}$ ) for up to two weeks, experienced declined capacity for detecting food sources and avoiding predator-associated scents (Porteus et al. 2021). However, these relatively short exposures resulted in marginal effects on gene expression of the olfactory bulb (Porteus et al. 2018; Williams et al. 2019).

In this study, we experimentally investigated intergenerational long-term consequences of OA on the olfactory epithelium transcriptome in F1 D. labrax. Specifically, we sought to understand how predicted end-of-century $\mathrm{OA}$ alters the olfactory system in a way that reflects long-term adaptations in F1 offspring, and how such changes might impact on overall robustness, such as survival after infection, a common problem in aquaculture. Cumulatively, we identified 9,000 OA-induced differentially expressed transcripts, representing roughly a third of the total number of transcripts (34\%), that revealed a profound modification of the $D$. labrax' olfactory epithelium transcriptomic profile.

Overall, among differently expressed genes, we identified genes broadly related to olfactory function. These included genes involved in ion balance, GABA signalling, olfactory neuronal signal transduction and neuron excitability, and their regulation reflected significant adaptations to synaptic plasticity (figure 4). We also observed transcriptome changes indicative of a metabolic depression in the olfactory epithelium, as exemplified by down-regulation of genes involved in ATP synthesis and the mitochondrial electron transport system [cytochrome c oxidase (cox) genes] in combination with lower expression of genes involved in energetically costly processes (e.g. macromolecules biosynthesis). At a general level, we also detected higher expression of genes related to the AMPK signalling pathway, consistent with related work in the brain of fish exposed to OA a well as in other marine species (Schunter et al. 2018; Cao et al. 2018). Extending from these findings, and unexpectedly, we also discovered that $D$. labrax, upon intergenerational exposure to $\mathrm{OA}$, up-regulated gene programs conferring elevated resistance to virus infection. Consistent with these molecular changes, we found in our betanodavirus infection study that 
the OA-exposed F1 cohort succumbed to infection later and that fewer fish died than control F1 fish (figure 4).

Across different organs in OA-exposed and control fish, virus presence and concentrations were similar, indicating that the viral infection in and of itself was similar, and that the difference in disease resistance was due to a superior defence relative to fish not exposed to OA. In related work, Bresolin de Souza and collaborators found that a three-month exposure to OA in Atlantic juvenile halibuts was associated with increased activity of complement component C3, lysozyme and fibrinogen, known factors in innate and complement systems though antiviral and inflammatory activities (Bresolin De Souza et al. 2014; Bresolin de Souza et al. 2016). Apart from this work, OA effects linked to immune function has been reported for shellfish (e.g. Leite Figueiredo et al., 2016; Castillo et al., 2017; Sun et al., 2017), but our insight into long-term adaptations for marine fish, and their potential ramifications for aquaculture remain largely unknown (Baag and Mandal 2022). As a progressively acidic marine environment will inevitably become a reality in the future, such knowledge is urgently needed. Here, we reveal for the first time that fish may acquire an improved capacity to resist a viral infection upon years of intergenerational exposure to OA. In our transcriptomic characterization of the olfactory epithelium of fish exposed to intergenerational $\mathrm{OA}$, we detected up-regulation of gene programs linked to innate antiviral immunity; pathogen receptors genes, Interferon-Stimulated Genes (ISG) and ribosome-related genes.

Detection of an invading pathogen is a critical first step in the initiation of a robust immune response (uncapped viral RNA/DNA and/or cell wall components) through Pattern recognition receptors (PRRs) (Janeway and Medzhitov 2002). In the OA-exposed F1 cohort, we detected a robust up-regulation of four out of the five types of PRRs relative to control F1 fish, suggesting an enriched extent of pathogen detection as a first contingency response upon viral invasion. Of note, these are germline-encoded genes, suggesting that their up-regulation can partly result from trade-offs in parents carried over to offspring, although our analysis does not allow us to distinguish this possibility from solely F1 generation adaptations. Of the up-regulated PRR classes, nucleotide oligomerization and binding domain (NOD)-like receptors (NLRs) NLRs were the most abundant. NLRs are barely present in mammals, but through evolution expanded into very large families in fish and other species lacking adaptive immunity (Howe et al. 2016). NLR can act as sterile and intracellular pathogen stress signal receptors and are therefore poised to play a central role in the inflammatory response (Laing et al. 2008; Levraud et al. 2019a) and homeostasis of microglia, the only central nervous system immune cells present in fish (Shiau et al. 2013; Wang et al. 2019).

The second PRR class, C-type lectin receptors (CLRs), mediate bacteria- and fungi-associated responses, but following viral recognition, can induce both protective and detrimental effects depending on the pathogen (Hoving et al. 2014). Members of the mannose receptor, the asialoglycoprotein receptor and ctype lectin domain families, were represented among the up-regulated CLR genes (additional file 2). Interestingly, the melanoma differentiation-associated protein 5 ( $m$ da 5 or ifih 1 ) gene, which encodes for a member of RLRs and several members of the TLRs gene family, both considered as key virus sensors 
were also up-regulated (Takeuchi and Akira 2009; Ranjan et al. 2009). Stimulation of MDA5 or TLRs by RNA viruses is known to result in type I interferon response activation (Langevin et al. 2013).

Interferons are signalling cytokines secreted by every type of cell in order to interfere with viral progression by regulating the expression of more than 1000 genes at the transcriptional level (Klamp et al. 2003; Paul et al. 2007; Li et al. 2009; Kuenzel et al. 2010). These genes are called Interferon-induced genes (ISG) and exhibit a wide array of antiviral properties (de Veer et al. 2001; Wang et al. 2017). A large proportion of orthologous ISGs have been identified in fish and humans and very few fish ISG have no human ortholog (e.g. gig1, gig2, vig-B319 (Levraud et al. 2019b)). The mechanisms of antiviral activity of fish-specific ISGs remain poorly understood (Schneider et al. 2014; Poynter and DeWitte-Orr 2016). Here, we found that OA-exposed fish expressed several up-regulated ISGs whose functions may partially explain their enhanced resistance to viral infection. These include the IFN-induced double-stranded RNAactivated protein kinases ( $p k r 1$, prkrir), a particular ISG subset that functions as PRR, antiviral effector, and inhibitors of virus translation and replication combined (Clemens and Elia 1997; Schneider et al. 2014; Poynter and DeWitte-Orr 2016); genes from the GTPase imap family (gimap8, 4, 7), known to mediate cell-autonomous resistance against pathogens (Haller and Kochs 2002; Klamp et al. 2003; Haller et al. 2007); and genes from the TRIM family $($ trim16, 39) that play pivotal role in viral restriction, modulation of immune signalling, autophagy and formation of cellular structures (Langevin et al. 2019). The regulation of ISG transcription can take place via the classical interferon mediated JAK-STAT signalling pathway (Darnell et al. 1994; Wang et al. 2017) and/or through a variety of non-canonical pathways independent of interferon induction (Mostafavi et al. 2016; Wang et al. 2017). Here, we found that genes involved in the JAK-STAT pathway were both up- and down- regulated in the OA-exposed fish cohort. To better understand ISG signalling pathway regulation in the context of viral infection in fish, analyses at the post transcriptional levels (e.g. phosphorylation status) for JAK-STAT and non-canonical pathways would be necessary.

Finally, we found that intergenerational exposure to OA triggered a down-regulation of genes coding for ribosome biogenesis, ribosomal proteins and eukaryotic translation initiation factors, indicative of reduced ribosome abundance and malfunction. This is confirmed by the GO analyses that show strong down-regulation of both translation and macromolecule biosynthetic process. During an infection, the virus hijacks the host ribosomes to produce new viral particles along with host cellular factors to initiate viral translation (Lee et al. 2013; Li 2019). We hypothesised that as OA induced a malfunction of the host's ribosomes, viruses may lack the biosynthetic machinery to translate and transcribe their nucleic acids. This, together with the up-regulation of PRRs and ISGs might explain the observed superior resistance during the viral challenge.

VNN outbreaks are considered one of the most relevant infectious constraint for the culture of a variety of fish species. Hence, the new insights we provide into how a marine teleost of economic interest undergoes intergenerational acclimation could be of precious concern to aquaculture. Although juvenile fish exposed to intergenerational acclimation were more resistant to VNN, based on the changed transcriptome, their metabolic and odour transduction programs were altered, which may in turn alter the 
olfactory perception of a wide array of chemical cues that may consequently impact odour-mediated behaviours including feeding, homing and other inter- or intra-specific interactions such as sociability, mating, competition and predator detection (figure 4). Understanding how the interplay between acidification and warming over generations modulate olfactory behaviour and viral resistance could be useful to develop new strategies for maintaining the health and production in aquaculture facilities for either commercial or scientific purposes.

\section{Conclusions}

We report here that intergenerational exposure to $\mathrm{OA}$ induces a deep modification of the transcriptomic profile in the olfactory epithelium of the $D$. labrax that include plastic responses related to ion balance and transport, neuronal activity and plasticity, energy metabolism and innate immunity (figure 4). This intergenerational plasticity may be considered as an acclimation (adaptive plasticity) to prevent more severe OA-induced physiological disruption at the whole organism level (Bailey et al. 2017; Schunter et al. 2018). It is noteworthy that immune system factors such as cytokines, interferons and interleukins also play a role in central nervous system and brain development, and can induce changes in neural network activity, supporting the intricated interplay between the immune and the nervous system (Mousa and Bakhiet 2013; Clarkson et al. 2017). Additional experimentations based on electrophysiology and behavioural tests would help determine whether the regulation that we observed in the neuronal plasticity and activity gene programs are associated with a perturbation of the olfactory function, as suggested by the regulation of key processes associated with energy metabolism. Likewise, further studies will be necessary to more globally characterize OA-induced effects on immune status in both cultured and wild fish and its capacity to resist the most fish pathogens in a changing ocean.

\section{Methods}

Animal experiments in this study were conducted following the European Commission recommendation 2007/526/EC and Directive 2010/63/EU for the accommodation and care of animals used for experimental and other scientific purposes. The OA conditioning was performed at the French Research Institute for Exploitation of the Sea (IFREMER) in Plouzané, within the facilities of the Laboratory of Adaptation, Reproduction and Nutrition of fishes (ARN) (Agreement number: B29-212-05). The viral challenge was performed at the French Agency for Food, Environmental and Occupational Health \& Safety (ANSES) in Plouzané (Agreement number: D29-212-3). Each procedure was the subject of a specific authorization issued by a French Ethics Committee for animal testing (APAFIS \#2018032209421223 for OA conditioning, and APAFIS \#202001161613768 for viral challenge).

\section{Animal husbandry and experimental setup}

F1 juveniles (2 years old) of the European sea bass Dicentrarchus labrax used in the present study originated from an in vitro fertilisation of 4 years old $\mathrm{F} 0$ parents exposed from larval to adult stages to control conditions ( pH8.0) or to OA conditions ( pH7.6) (Crespel et al. 2017; Cominassi et al. 2019; 
Howald et al. 2019; Cominassi et al. 2020; Mazurais et al. 2020). Sperm and eggs were collected and pooled from 20 males and 6 females of each pH-treatment (see methodological summary in figure 1). Luteinizing hormone releasing hormone (LHRH) was injected to stimulate synchrony in oocytes full maturation. Taking great care of maintaining parental $\mathrm{pH}$ conditions, eggs were hatched and the resultant $\mathrm{F} 1$ offspring were reared in water at the same $\mathrm{pH}$ as their parents. Rearing conditions during larval and juvenile stages were similar to those described in previous studies (Howald et al. 2019; Cominassi et al. 2020; Mazurais et al. 2020). For both treatments, seawater temperature and salinity followed seasonality of the Bay of Brest. 402 juveniles (201 per treatment) were distributed evenly in 6 culture tanks ( $400 \mathrm{~L}$, three tanks = three replicas per treatment) that were part of an open-circuit system. To guarantee high quality, seawater pumped $500 \mathrm{~m}$ off the coastline at a depth of $20 \mathrm{~m}$ passed through a sand filter, a tungsten heater, a degassing column packed with plastic rings, a 2- $\mu \mathrm{m}$ filter membrane, and a UV lamp. Seawater for the control treatment was then poured into each of the three replicas tanks. Seawater for the $\mathrm{OA}$ treatment was injected with $\mathrm{CO}_{2}$ (through manipulation of a flowmeter (Aalborg, USA) connected to a $\mathrm{CO}_{2}$ bottle (Air Liquide, France)) in a header tank equipped with a degassing $\mathrm{CO}_{2}$ column to favour mixing. Then, low $\mathrm{pH}$ seawater was poured into each of the 3 replicas tanks. $\mathrm{pH}$ in NIST scale and temperature in the six tanks were daily measured with a WTW 3110 pH meter (Xylem Analytics Germany, Weilheim, Germany; with electrode: WTW Sentix 41) calibrated daily with pH4.0 and pH7.0 buffers (WTW, Germany). Total alkalinity was measured once a week following the protocol of Strickland and Parsons (Strickland and Parsons 1972): a $50 \mathrm{ml}$ sample of tank water was mixed with $15 \mathrm{ml} \mathrm{HCl}(0.01 \mathrm{M})$ and pH was measured immediately. Total alkalinity was then calculated with the following formula:

$$
T A=\frac{V_{H C l} * C_{H C L}}{V_{\text {sample }}}-\frac{\left(V_{H C l}+V_{\text {sample }}\right)}{V_{\text {sample }}} * \frac{\left\{H^{+}\right\}}{\square H^{+}},\left[\frac{\mathrm{mol}}{l}\right]
$$

with, total alkalinity $\left(\mathrm{TA}, \mathrm{mol} \mathrm{I}^{-1}\right)$, volume $(\mathrm{V}, \mathrm{I})$ of $\mathrm{HCl}$ or of the sample, concentration $\left(\mathrm{C}, \mathrm{mol} \mathrm{I}^{-1}\right)$ of $\mathrm{HCl}$, hydrogen activity $\left(\mathrm{H}^{+}, 10^{-\mathrm{pH}}\right)$ and hydrogen activity coefficient $\left(\mathrm{YH}^{+}\right.$, here $\left.=0.758\right)$. $\mathrm{F} 1$ juveniles were fed ad libitum with a diet that meets their nutritional requirements (Vitalis Cal, Skretting, Stavanger, Norway). No significant difference was observed in the mean weights ( $t$ test, $t=0.02, \mathrm{df}=64.52, \mathrm{p}$-value $=0.98$ ) of the 2-year-old juveniles between the two treatments $(n=35)$. F1 juveniles from the two treatments behaved and fed in a relatively similar way. Mortality events were not detected.

\section{RNA extraction}

Prior to sampling, fish were fasted for $24 \mathrm{~h}$. Then, 2-year-old juveniles were first anesthetized $\left(20 \mathrm{mg} \mathrm{L}^{-1}\right)$, and then euthanized with a lethal dose $\left(200 \mathrm{mg} \mathrm{L}^{-1}\right)$ of tricaine methane sulfonate 222 (MS222, Pharmaq, Fordingbridge, Hampshire, UK). Sampling consisted in dissecting the olfactory rosette from 7 individuals per treatment that were quickly stored in RNA Stabilization Reagent (RNAlater, Qiagen, Hilden, Germany) following recommendations from the supplier. Total RNA was extracted using Extract-All reagent 
(Eurobio, Courtaboeuf, Essonne, France) combined with Nucleospin RNA column that includes one step of DNase treatment (Macherey-Nagel, Düren, Germany) according to the manufacturer's instructions. The concentration and purity of extracted RNA were verified (ratio>2) using an ND-1000 NanoDrop ${ }^{\circledR}$ spectrophotometer (Thermo Scientific Inc., Waltham, MA, USA). The integrity of RNA was checked by electrophoresis using an Agilent Bioanalyzer 2100 (Agilent Technologies Inc., Santa Clara, CA, USA). All samples showed an RNA integrity (RIN) score $>9$. RNA samples were stored at $-80^{\circ} \mathrm{C}$ for further RNA sequencing and qPCR analyses.

\section{RNA-Sequencing analysis}

RNA samples extracted from the olfactory rosettes were sent to the sequencing platform GenomiX (MGX, Montpellier, France) for transcriptome analysis through RNA sequencing (RNA-Seq).

cDNA Libraries: Libraries of cDNA were constructed using TruSeq Stranded mRNA kit (Illumina, San Diego, CA, USA) according to the manufacturer's instructions. Briefly, poly-A RNAs were purified using oligo-d(T) magnetic beads from 863ng of total RNA. Poly-A RNAs were fragmented and underwent a reverse transcription using random hexamers. During the second strand generation step, dUTP substituted dTTP in order to prevent the second strand to be used as a matrix during the final PCR amplification. Double stranded cDNAs were adenylated at their 3 ' ends and ligated to Illumina's indexes. Ligated cDNAs were amplified following 15 PCR cycles. PCR products were purified using AMPure XP Beads (Beckman Coulter Genomics, Brea, CA, USA). Libraries were validated using Standard Sensitivity NGS kit on Fragment Analyzer (Agilent Technologies, Santa Clara, CA, USA).

Libraries sequencing: Fourteen libraries were pooled in equimolar amounts. The balance between all samples of the pool was assessed by using KAPA Library quantification kit (Roche, Bâle, CHE). The pool was then sequenced on a Novaseq 6000 (Illumina, San Diego, CA, USA) on a SP flow cell in single-read $100 \mathrm{nt}$ mode according to the manufacturer's instructions. This sequencing produced between 40 and 50 million passed filter clusters per library.

Sequencing quality control: Image analyses and base calling were performed using the NovaSeq Control Software and Real-Time Analysis component (Illumina, San Diego, CA, USA). Demultiplexing and trimming were performed using Illumina's conversion software (bcl2fastq 2.20). The quality of the raw data was assessed using FastQC from the Babraham Institute and the Illumina software SAV (Sequencing Analysis Viewer). FastqScreen was used to estimate the potential level of contamination.

\section{Transcriptomic and Gene Ontology (GO) analysis}

Raw reads mapping and gene quantification were done using STAR aligner (v2.7.2c) (Dobin et al. 2013) to the $D$. labrax reference genome guided by the reference gene annotation (Tine et al. 2014). Differential expression analysis was performed with the DESeq2 package (Bioconductor) (Love et al. 2014) using an adjusted p-value cut-off of 0.01 . The SRR accession numbers for the raw sequence data are SRR15222852-65. Cbln11 structural annotation was carried out manually in GenomeView (Abeel et al. 2012) based on BlastHit of Cbln 11 sequences available at NCBI and from mapped RNA-Seq reads. Gene 
structure was exported in gtf format and added to the current annotation. The datasets supporting the conclusions of this article are available in the SRA repository under accession numbers: SRR1522285965 (https://www.ncbi.nlm.nih.gov/sra/?term=SRR15222852) and SRR15222852-58 (https://www.ncbi.nlm.nih.gov/sra/?term=SRR15222859).

To extract biological meaningfulness and to visualize potentially affected pathways, a Gene ontology (GO) enrichment analyses was performed separately on significantly up- or down-regulated genes under OA. Raw reads from RNA-Seq were imported into Galaxy instance of Ifremer (Augusto et al. 2017). An obo GO file and the product annotation file for $D$. labrax (Tine et al. 2014) were used to analyse significantly $(p<0.01)$ up or down-regulated genes. FDR was corrected with the Benjamini-Hochberg test. The corrected p-value to apply to the graph output was set to 0.01 .

\section{qPCR validation}

To validate some results from the transcriptomic analysis, qPCRs were performed. iScript ${ }^{\mathrm{TM}} \mathrm{cDNA}$ Synthesis kit (Bio-Rad Laboratories Inc., Hercules, CA, USA) was used to reverse transcribe in duplicate $500 \mathrm{ng}$ of DNase-treated RNA samples into first strand cDNA by following conditions provided by the manufacturer. Negative RT consisting in RT reaction without retro-transcriptase enzyme were also performed for all samples. The relative quantification of mRNA exhibiting differential expression through the RNA-Seq approach [SAM and HD domain containing deoxynucleoside triphosphate triphosphohydrolase 1 (samhd1), Interferon-induced very large GTPase 1 (gvinp1), Toll-Like Receptor 3 (t/r3), Chemokine C-X-C motif ligand 14 (cxc/14), Nuclear factor of activated T-cells 5 (nfat5)] was performed by qPCR using primers designed for the assembled transcripts and blasted using the NCBI BLAST tool to verify specificity (additional file 1). Elongation factor 1-alpha (ef1a) and Ribosomal Protein L13a (rpl13a) were tested as housekeeping genes for normalization but only rpl13a was used since ef1a did not meet the acceptance criteria in terms of gene expression stability measure (M) and coefficient of variation (CV).

The efficiency of the qPCR reaction tested for each primer pair through standard curves were around $100 \%$ with R2 $>0.999$. Transcript expression was quantified using the CFX96 Touch Real-Time PCR Detection system (Bio-Rad Laboratories Inc.) and the protocol previously described (Mazurais et al. 2020).

\section{Viral Challenge experiment}

Betanodavirus strain W80 isolated from diseased $D$. labrax displaying typical signs of VNN was used in this study. According to Castri et al. (Castri et al. 2001), a stock of virus was produced at $24^{\circ} \mathrm{C}$ on the SSN-1 (Striped Snakehead fish; Ophicephalus striatus) cell line (L15 medium, 10\% FBS, pH7.6) and frozen. Cell debris was removed by centrifugation for $15 \mathrm{~min}$ at $2000 \mathrm{~g}$; the virus was then aliquoted and stored at $-80^{\circ} \mathrm{C}$. Before the challenge, viral titration was carried out on one of the aliquots after a single freeze-thaw cycle based on the tissue culture infectious dose technique $\left(\mathrm{TCID}_{50}\right)$ described by (Dussauze 
et al. 2015). The infectious titer of the viral production was calculated according to the method of Kärber (Kärber 1931), and was found to be $1 \times 10^{8} \mathrm{TCID}_{50} / \mathrm{mL}$.

After 2-years rearing of the F1, 148 juveniles per treatment were divided into four flow through tanks of $400 \mathrm{~L}$ (figure 1) and were challenged by immersion in a bath with $\mathrm{W} 80$ at $25^{\circ} \mathrm{C}$ to mimic the environmental conditions where the clinical signs of disease were reported. For the viral challenge, the water flow was interrupted, the oxygenation was increased and the water volume was reduced to $100 \mathrm{~L}$. Three out of four tanks per treatment were exposed for $3 \mathrm{~h}$ with an infectious dose of $5.10^{4} \mathrm{TCID}_{50} / \mathrm{mL}^{-1}$ of W80. The fourth tank per treatment was exposed in the same conditions to SSN-1 cell supernatant free from the virus and used as a negative control without virus. After a 3-hours bath exposure, the water flow was restored to slowly dilute the virus titration. The system was maintained open and the water temperature $\left(25^{\circ} \mathrm{C} \pm 2^{\circ} \mathrm{C}\right.$ ) was continually measured and recorded with a wireless probe (Cobalt, Oceasoft $\circledast$ ) coupled to an acquisition system (ThermoClient 4.1.0.24). Juveniles were fed once a day with commercial pellets (Neo Start Coul 2 from Le Gouessant Aquaculture) except on the day of the viral infection.

Mortality was recorded twice a day during 45 days post-infection (dpi). Dead fish were stored at $-20^{\circ} \mathrm{C}$ until viral examination. The presence and concentration of the virus was checked on a pool of organs (spleen, kidney, heart, brain). Virus concentrations were determined in six fish that died at the peak of mortality during the viral challenge (9 dpi in the control treatment; $11 \mathrm{dpi}$ in OA treatment) and in five survivor fish per treatment by immunofluorescence assay on the SSN-1 and E11 cell lines according to the adapted protocol by Dussauze et al. (Dussauze et al. 2015).

Survival curves were estimated using the Kaplan-Meier method and were compared by a log rank analysis using the online platform BiostaTGV. Firstly, survival curves for each replica within each treatment were compared, and if no significant difference was observed, results from the 3 replicas per treatment were pooled. In case of significant difference, each replica was analysed separately and compared to the other treatment. In addition, a Kruskal-Wallis test together with a Dunn's post hoc test were performed (XLSTAT software 2020) to determine whether the Mean Day to Death (MDD) and the final survival rate varied with treatment.

\section{Declarations}

Ethics approval and consent to participate: As indicated in the Methods section, our two experiments followed European Commission recommendations on fish ethics and well-being and were authorized by the French Ethics Committee for animal testing (APAFIS \#2018032209421223 and APAFIS \#202001161613768).

Consent for publication: Not applicable.

Availability of data and materials: The datasets generated and analysed in this article are available in the SRA repository under accession numbers: SRR15222859-65 and SRR15222852-58 
(https://www.ncbi.nlm.nih.gov/sra/?term=SRR15222852 and https://www.ncbi.nlm.nih.gov/sra/? term=SRR15222859).

Competing interests: The authors declare that they have no competing interests.

Funding: The is study was supported by the AWI-MARUM-IFREMER AMI Partnership Programme (DEADLY TRIO project), LabexMer (ANR-10LABX-0019, OASYS project), the Ministry of Ecological and Solidarity Transition and the Foundation for Biodiversity Research (Ocean Acidification Program, PACIO project), the Deutsche Forschungsgemeinschaft, PE 1157/8-1, MA4271/3-1 (the FITNESS project) and France Génomique National infrastructure, funded as part of "Investissement d'Avenir" program managed by Agence Nationale pour la Recherche (contract ANR-10-INBS-09).

Authors' contributions: DM \& FM conceived the scientific questions and experimental design. DM collected RNA samples and TV extracted the RNA and verified RNA quality and integrity. A-AG performed the RNA sequencing. MC-R, AC \& CN performed the transcriptomic and Gene Ontology analysis. LM performed qPCR's. MD \& JC conducted the viral challenge experiment and treated and analysed the outcoming data. MB provided ideas concerning olfactory behaviour. MC-R \& DM led the writing of the manuscript. All authors contributed significantly to the revision of the manuscript and approved it for publication.

Acknowledgements: The authors are grateful to Christina Lilliehook from Life Science Editors for editing services.

\section{References}

Abeel T, Van Parys T, Saeys Y, et al (2012) GenomeView: a next-generation genome browser. Nucleic Acids Res 40:e12-e12. doi: 10.1093/nar/gkr995

Ashur MM, Johnston NK, Dixson DL (2017) Impacts of ocean acidification on sensory function in marine organisms. Integr Comp Biol 57:63-80. doi: 10.1093/icb/icx010

Augusto R de C, Tetreau G, Chan P, et al (2017) Double impact: natural molluscicide for schistosomiasis vector control also impedes development of Schistosoma mansoni cercariae into adult parasites. PLoS Negl Trop Dis 11:1-19. doi: 10.1371/journal.pntd.0005789

Baag S, Mandal S (2022) Combined effects of ocean warming and acidification on marine fish and shellfish: A molecule to ecosystem perspective. Sci Total Environ 802:149807. doi:

https://doi.org/10.1016/j.scitotenv.2021.149807

Bailey A, De Wit P, Thor P, et al (2017) Regulation of gene expression is associated with tolerance of the Arctic copepod Calanus glacialis to CO2-acidified sea water. Ecol Evol 7:7145-7160. doi:

10.1002/ece3.3063 
Bandín I, Souto S (2020) Betanodavirus and VER Disease: A 30-year. Pathogens 9:1-46.

Bibby R, Widdicombe S, Parry $\mathrm{H}$, et al (2008) Effects of ocean acidification on the immune response of the blue mussel Mytilus edulis . Aquat Biol 2:67-74.

Bindoff NL, Cheung WWL, Kairo J, et al (2019) Changing Ocean, Marine Ecosystems, and Dependent Communities. In: Pörtner H-O, Roberts D, V M-D, et al. (eds) IPCC Special Report on the Ocean and Cryosphere in a Changing Climate. In Press,

Bresolin de Souza K, Asker N, Jönsson E, et al (2016) Increased activity of lysozyme and complement system in Atlantic halibut exposed to elevated $\mathrm{CO} 2$ at six different temperatures. Mar Environ Res 122:143-147. doi: 10.1016/j.marenvres.2016.09.005

Bresolin De Souza K, Jutfelt F, Kling P, et al (2014) Effects of increased CO2on fish gill and plasma proteome. PLoS One. doi: 10.1371/journal.pone.0102901

Breuil G, Bonami JR, Pepin JF, Pichot Y (1991) Viral infection (picorna-like virus) associated with mass mortalities in hatchery-reared sea-bass (Dicentrarchus labrax) larvae and juveniles. Aquaculture 97:109116. doi: 10.1016/0044-8486(91)90258-9

Cadwell K (2016) Crosstalk between autophagy and inflammatory signalling pathways: balancing defence and homeostasis. Nat Rev Immunol 16:661-675. doi: 10.1038/nri.2016.100

Caldeira K, Wickett ME (2003) Anthropogenic carbon and ocean pH. Nature 425:365-365. doi: $10.1038 / 425365 a$

Cao R, Liu Y, Wang Q, et al (2018) Seawater Acidification Reduced the Resistance of Crassostrea gigas to Vibrio splendidus Challenge: An Energy Metabolism Perspective. Front Physiol 9:880. doi:

10.3389/fphys.2018.00880

Castillo N, Saavedra LM, Vargas CA, et al (2017) Ocean acidification and pathogen exposure modulate the immune response of the edible mussel Mytilus chilensis. Fish Shellfish Immunol 70:149-155. doi: 10.1016/j.fsi.2017.08.047

Castri J, Thiéry R, Jeffroy J, et al (2001) Sea bream Sparus aurata, an asymptomatic contagious fish host for nodavirus. Dis Aquat Organ 47:33-38. doi: 10.3354/dao047033

Cavicchioli R, Ripple WJ, Timmis KN, et al (2019) Scientists' warning to humanity: microorganisms and climate change. Nat Rev Microbiol 17:569-586. doi: 10.1038/s41579-019-0222-5

Chivers DP, Mccormick MI, Nilsson GE, et al (2014) Impaired learning of predators and lower prey survival under elevated CO2: A consequence of neurotransmitter interference. Glob Chang Biol 20:515-522. doi: 10.1111/gcb.12291 
Chung W-S, Marshall NJ, Watson S-A, et al (2014) Ocean acidification slows retinal function in a damselfish through interference with GABAA receptors. J Exp Biol 217:323-326. doi: 10.1242/jeb.092478

Claiborne JB, Blackston CR, Choe KP, et al (1999) A mechanism for branchial acid excretion in marine fish: identification of multiple $\mathrm{Na}+/ \mathrm{H}+$ antiporter $(\mathrm{NHE})$ isoforms in gills of two seawater teleosts. $\mathrm{J}$ Exp Biol 202:315-324.

Claiborne JB, Edwards SL, Morrison-Shetlar Al (2002) Acid-base regulation in fishes: cellular and molecular mechanisms. J Exp Zool 293:302-319. doi: 10.1002/jez.10125

Clarkson BDS, Kahoud RJ, McCarthy CB, Howe CL (2017) Inflammatory cytokine-induced changes in neural network activity measured by waveform analysis of high-content calcium imaging in murine cortical neurons. Sci Rep 7:9037. doi: 10.1038/s41598-017-09182-5

Clemens MJ, Elia A (1997) The double-stranded RNA-dependent protein kinase PKR: structure and function. J Interf cytokine Res Off J Int Soc Interf Cytokine Res 17:503-524. doi:

$10.1089 /$ jir.1997.17.503

Clements JC, Hunt HL (2015) Marine animal behaviour in a high CO2 ocean. Mar Ecol Prog Ser 536:259279. doi: $10.3354 / \operatorname{meps} 11426$

Collados Rodríguez M (2020) The Fate of Speckled Protein 100 (Sp100) During Herpesviruses Infection. Front Cell Infect Microbiol 10:607526. doi: 10.3389/fcimb.2020.607526

Cominassi L, Moyano M, Clai G, et al (2020) Food availability modulates the combined effects of ocean acidification and warming on fish growth. 1-12. doi: 10.1038/s41598-020-58846-2

Cominassi L, Moyano M, Claireaux G, et al (2019) Combined effects of ocean acidification and temperature on larval and juvenile growth, development and swimming performance of European sea bass (Dicentrarchus labrax). PLoS One 14:1-22. doi: 10.1371/journal.pone.0221283

Costa JZ, Thompson KD (2016) Understanding the interaction between Betanodavirus and its host for the development of prophylactic measures for viral encephalopathy and retinopathy. Fish Shellfish Immunol 53:35-49. doi: 10.1016/j.fsi.2016.03.033

Crespel A, Zambonino-Infante J-L, Mazurais D, et al (2017) The development of contemporary European sea bass larvae (Dicentrarchus labrax) is not affected by projected ocean acidification scenarios. Mar Biol 164:155. doi: 10.1007/s00227-017-3178-x

Danovaro R, Corinaldesi C, Dell'anno A, et al (2011) Marine viruses and global climate change. FEMS Microbiol Rev 35:993-1034.

Darnell JE, Kerr IM, Stark GR (1994) Jak-STAT pathways and transcriptional activation in response to IFNs and other extracellular signaling proteins. Science (80- ) 264:1415-1421. doi: 
de Veer MJ, Holko M, Frevel M, et al (2001) Functional classification of interferon-stimulated genes identified using microarrays. J Leukoc Biol 69:912-20. doi: 10.1189/jlb.1106655

Dixson DL, Munday PL, Jones GP (2010) Ocean acidification disrupts the innate ability of fish to detect predator olfactory cues. Ecol Lett 13:68-75. doi: 10.1111/j.1461-0248.2009.01400.x

Dlugokencky E, Tans P (2021) Trends in atmospheric carbon dioxide. In: NOAA/ESRL. https//www.esrl.noaa.gov/gmd/ccgg/trends/mlo.html. Accessed Sept. 232021. https://www.esrl.noaa.gov/gmd/ccgg/trends/mlo.html. Accessed 23 Sep 2020

Dobin A, Davis CA, Schlesinger F, et al (2013) STAR: ultrafast universal RNA-seq aligner. Bioinformatics 29:15-21. doi: 10.1093/bioinformatics/bts635

Dussauze M, Danion M, Le Floch S, et al (2015) Growth and immune system performance to assess the effect of dispersed oil on juvenile sea bass (Dicentrarchus labrax). Ecotoxicol Environ Saf 120:215-222. doi: 10.1016/j.ecoenv.2015.05.018

Esbaugh AJ (2017) Physiological implications of ocean acidification for marine fish: Emerging patterns and new insights. J Comp Physiol B 188:1-13. doi: 10.1007/s00360-017-1105-6

Faria AM, Lopes AF, Silva CSE, et al (2018) Reproductive trade-offs in a temperate reef fish under high pCO2 levels. Mar Environ Res 137:8-15. doi: 10.1016/j.marenvres.2018.02.027

Fensterl V, Sen GC (2015) Interferon-induced Ifit proteins: their role in viral pathogenesis. J Virol 89:24622468. doi: $10.1128 / J V I .02744-14$

Fensterl V, Wetzel JL, Ramachandran S, et al (2012) Interferon-induced Ifit2/ISG54 protects mice from lethal VSV neuropathogenesis. PLoS Pathog 8:e1002712-e1002712. doi: 10.1371/journal.ppat.1002712

Haller O, Kochs G (2002) Interferon-Induced Mx Proteins: Dynamin-Like GTPases with Antiviral Activity. Traffic 3:710-717. doi: https://doi.org/10.1034/j.1600-0854.2002.31003.x

Haller O, Staeheli P, Kochs G (2007) Interferon-induced Mx proteins in antiviral host defense. Biochimie 89:812-818. doi: 10.1016/j.biochi.2007.04.015

Hamilton TJ, Holcombe A, Tresguerres M (2014) CO 2 -induced ocean acidification increases anxiety in Rockfish via alteration of GABA A receptor functioning. Proc R Soc B Biol Sci 281:20132509. doi: 10.1098/rspb.2013.2509

Hansen JD, La Patra S (2002) Induction of the rainbow trout MHC class I pathway during acute IHNV infection. Immunogenetics 54:654-661. doi: 10.1007/s00251-002-0509-x 
Hassenrück C, Fink A, Lichtschlag A, et al (2016) Quantification of the effects of ocean acidification on sediment microbial communities in the environment: the importance of ecosystem approaches. FEMS Microbiol Ecol. doi: 10.1093/femsec/fiw027

Heuer RM, Grosell M (2014) Physiological impacts of elevated carbon dioxide and ocean acidification on fish. Am J Physiol - Regul Integr Comp Physiol 307:R1061-R1084. doi: 10.1152/ajpregu.00064.2014

Holmberg RJ, Wilcox-Freeburg E, Rhyne AL, et al (2019) Ocean acidification alters morphology of all otolith types in Clark's anemonefish (Amphiprion clarkii). PeerJ 2019:1-25. doi: 10.7717/peerj.6152

Hoving JC, Wilson GJ, Brown GD (2014) Signalling C-Type lectin receptors, microbial recognition and immunity. Cell Microbiol 16:185-194. doi: 10.1111/cmi.12249

Howald S, Cominassi L, LeBayon N, et al (2019) Future Ocean warming may prove beneficial for the northern population of European seabass, but ocean acidification does not. J Exp Biol jeb213017:1-10. doi: $10.1242 /$ jeb. 213017

Howe K, Schiffer PH, Zielinski J, et al (2016) Structure and evolutionary history of a large family of NLR proteins in the zebrafish. Open Biol. doi: 10.1098/rsob.160009

Hutchins DA, Fu F (2017) Microorganisms and ocean global change. Nat Microbiol 2:17058. doi: 10.1038/nmicrobiol.2017.58

IPCC (2014) Climate Change 2014: Synthesis Report. Contribution of Working Groups I, II and III to the Fifth Assessment Report of the Intergovernmental Panel on Climate Change, IPCC. IPCC, Geneva, Janeway CA, Medzhitov R (2002) Innate Immune Recognition. Annu Rev Immunol 20:197-216. doi: 10.1146/annurev.immunol.20.083001.084359

Jensen I, Robertsen B (2002) Effect of double-stranded RNA and interferon on the antiviral activity of Atlantic salmon cells against infectious salmon anemia virus and infectious pancreatic necrosis virus. Fish Shellfish Immunol 13:221-241. doi: https://doi.org/10.1006/fsim.2001.0397

Jiahuan R, Wenhao S, Xiaofan G, et al (2018) Ocean Acidification Impairs Foraging Behavior by Interfering With Olfactory Neural Signal Transduction in Black Sea Bream, Acanthopagrus schlegelii. Front Physiol 9:1-12. doi: 10.3389/fphys.2018.01592

Kärber G (1931) Beitrag zur kollektiven Behandlung pharmakologischer Reihenversuche. Naunyn Schmiedebergs Arch Exp Pathol Pharmakol 162:480-483. doi: 10.1007/BF01863914

Kim CY, Zhang X, Witola WH (2018) Small GTPase Immunity-Associated Proteins Mediate Resistance to Toxoplasma gondii Infection in Lewis Rat. Infect Immun. doi: 10.1128/IAI.00582-17 
Kishore U, Gaboriaud C, Waters P, et al (2004) C1q and tumor necrosis factor superfamily: modularity and versatility. Trends Immunol 25:551-561. doi: https://doi.org/10.1016/j.it.2004.08.006

Klamp T, Boehm U, Schenk D, et al (2003) A Giant GTPase, Very Large Inducible GTPase-1, Is Inducible by IFNs. J Immunol 171:1255-1265. doi: 10.4049/jimmunol.171.3.1255

Koppang EO, Dannevig BH, Lie $\varnothing$, et al (1999) Expression of Mhc class I and II mRNA in a macrophagelike cell line (SHK-1) derived from Atlantic salmon, Salmo salar L., head kidney. Fish Shellfish Immunol 9:473-489. doi: 10.1006/fsim.1999.0213

Kuenzel S, Till A, Winkler M, et al (2010) The Nucleotide-Binding Oligomerization Domain-Like Receptor NLRC5 Is Involved in IFN-Dependent Antiviral Immune Responses. J Immunol 184:1990-2000. doi: 10.4049/jimmunol.0900557

Lai F, Fagernes CE, Bernier NJ, et al (2017) Responses of neurogenesis and neuroplasticity related genes to elevated CO2 levels in the brain of three teleost species. Biol Lett. doi: 10.1098/rsbl.2017.0240

Laing KJ, Purcell MK, Winton JR, Hansen JD (2008) A genomic view of the NOD-like receptor family in teleost fish: Identification of a novel NLR subfamily in zebrafish. BMC Evol Biol 8:1-15. doi: 10.1186/1471-2148-8-42

Langevin C, Aleksejeva E, Passoni G, et al (2013) The antiviral innate immune response in fish: Evolution and conservation of the IFN system. J Mol Biol 425:4904-4920. doi: 10.1016/j.jmb.2013.09.033

Langevin C, Levraud J-P, Boudinot P (2019) Fish antiviral tripartite motif (TRIM) proteins. Fish Shellfish Immunol 86:724-733. doi: 10.1016/j.fsi.2018.12.008

Le Breton A, Grisez L, Sweetman J, Ollevier F (1997) Viral nervous necrosis (VNN) associated with mass mortalities in cage-reared sea bass, Dicentrarchus labrax (L.). J Fish Dis 20:145-151. doi: 10.1046/j.1365-2761.1997.00284.x

Lee ASY, Burdeinick-Kerr R, Whelan SPJ (2013) A ribosome-specialized translation initiation pathway is required for cap-dependent translation of vesicular stomatitis virus mRNAs. Proc Natl Acad Sci U S A 110:324-329. doi: 10.1073/pnas. 1216454109

Leite Figueiredo DA, Branco PC, dos Santos DA, et al (2016) Ocean acidification affects parameters of immune response and extracellular $\mathrm{pH}$ in tropical sea urchins Lytechinus variegatus and Echinometra luccunter. Aquat Toxicol 180:84-94. doi: 10.1016/j.aquatox.2016.09.010

Levraud J-P, Jouneau L, Briolat V, et al (2019a) IFN-Stimulated Genes in Zebrafish and Humans Define an Ancient Arsenal of Antiviral Immunity. J Immunol 203:3361-3373. doi: 10.4049/jimmunol.1900804

Levraud J-P, Jouneau L, Briolat V, et al (2019b) IFN-Stimulated Genes in Zebrafish and Humans Define an Ancient Arsenal of Antiviral Immunity. J Immunol 203:3361-3373. doi: 10.4049/jimmunol.1900804 
Li G, Zhang J, Sun Y, et al (2009) The evolutionarily dynamic IFN-inducible GTPase proteins play conserved immune functions in vertebrates and cephalochordates. Mol Biol Evol 26:1619-1630. doi: 10.1093/molbev/msp074

Li S (2019) Regulation of Ribosomal Proteins on Viral Infection. Cells 8:508. doi: 10.3390/cells8050508

Li T, Shan S, Wang L, et al (2018) Identification of a fish-specific NOD-like receptor subfamily C (NLRC) gene from common carp (Cyprinus carpio L.): Characterization, ontogeny and expression analysis in response to immune stimulation. Fish Shellfish Immunol 82:371-377. doi: 10.1016/j.fsi.2018.08.045

Liu J, Weinbauer MG, Maier C, et al (2010) Effect of ocean acidification on microbial diversity and on microbe-driven biogeochemistry and ecosystem functioning. Aquat Microb Ecol 61:291-305. doi: 10.3354/ame01446

Love MI, Huber W, Anders S (2014) Moderated estimation of fold change and dispersion for RNA-seq data with DESeq2. Genome Biol 15:550. doi: 10.1186/s13059-014-0550-8

Mackenzie CL, Lynch SA, Culloty SC, Malham SK (2014) Future oceanic warming and acidification alter immune response and disease status in a commercial shellfish species, Mytilus edulis L. PLoS One. doi: 10.1371/journal.pone.0099712

Magnadottir B, Audunsdottir SS, Bragason BT, et al (2011) The acute phase response of Atlantic cod (Gadus morhua): Humoral and cellular response. Fish Shellfish Immunol 30:1124-1130. doi: 10.1016/j.fsi.2011.02.010

Matsuo A, Oshiumi H, Tsujita T, et al (2008) Teleost TLR22 recognizes RNA duplex to induce IFN and protect cells from birnaviruses. J Immunol 181:3474-3485. doi: 10.4049/jimmunol.181.5.3474

Mazurais D, Servili A, Noel C, et al (2020) Transgenerational regulation of cbln11 gene expression in the olfactory rosette of the European sea bass (Dicentrarchus labrax) exposed to ocean acidification. Mar Environ Res 159:105022. doi: 10.1016/j.marenvres.2020.105022

Migliaccio O, Pinsino A, Maffioli E, et al (2019) Living in future ocean acidification, physiological adaptive responses of the immune system of sea urchins resident at a $\mathrm{CO} 2$ vent system. Sci Total Environ 672:938-950. doi: https://doi.org/10.1016/j.scitotenv.2019.04.005

Miller GM, Watson SA, Donelson JM, et al (2012) Parental environment mediates impacts of increased carbon dioxide on a coral reef fish. Nat Clim Chang 2:858-861. doi: 10.1038/nclimate1599

Mori I, Nishiyama Y, Yokochi T, Kimura Y (2005) Olfactory transmission of neurotropic viruses. J Neurovirol 11:129-137. doi: 10.1080/13550280590922793

Mostafavi S, Yoshida H, Moodley D, et al (2016) Parsing the Interferon Transcriptional Network and Its Disease Associations. Cell 164:564-578. doi: https://doi.org/10.1016/j.cell.2015.12.032 
Mousa A, Bakhiet M (2013) Role of cytokine signaling during nervous system development. Int J Mol Sci 14:13931-13957. doi: 10.3390/ijms140713931

Munday BL, Kwang J, Moody N (2002) Betanodavirus infections of teleost fish: a review. J Fish Dis 25:127-142. doi: 10.1046/j.1365-2761.2002.00350.x

Munday PL (2014) Transgenerational acclimation of fishes to climate change and ocean acidification. F1000Prime Rep 6:1-7. doi: 10.12703/P6-99

Munday PL, Dixson DL, Donelson JM, et al (2009) Ocean acidification impairs olfactory discrimination and homing ability of a marine fish. Proc Natl Acad Sci U S A 106:1848-1852. doi: 10.1073/pnas.0809996106

Nilsson GE, Dixson DL, Domenici P, et al (2012) Near-future carbon dioxide levels alter fish behaviour by interfering with neurotransmitter function. Nat Clim Chang 2:201-204. doi: 10.1038/nclimate1352

Ogura Y, Sutterwala FS, Flavell RA (2006) The inflammasome: first line of the immune response to cell stress. Cell 126:659-662. doi: 10.1016/j.cell.2006.08.002

Ohtani M, Hikima J, Kondo H, et al (2011) Characterization and antiviral function of a cytosolic sensor gene, MDA5, in Japanese flounder, Paralichthys olivaceus. Dev Comp Immunol 35:554-562. doi: https://doi.org/10.1016/j.dci.2010.12.013

Okamura Y, Morimoto N, Ikeda D, et al (2020) Interleukin-17A/F1 Deficiency Reduces Antimicrobial Gene Expression and Contributes to Microbiome Alterations in Intestines of Japanese medaka (Oryzias latipes). Front Immunol 11:425. doi: 10.3389/fimmu.2020.00425

Orr JC, Fabry VJ, Aumont O, et al (2005) Anthropogenic ocean acidification over the twenty-first century and its impact on calcifying organisms. Nature 437:681-6. doi: 10.1038/nature04095

Ozato K, Shin D-M, Chang T-H, Morse HC 3rd (2008) TRIM family proteins and their emerging roles in innate immunity. Nat Rev Immunol 8:849-860. doi: 10.1038/nri2413

Paul S, Ricour C, Sommereyns C, et al (2007) Type I interferon response in the central nervous system. Biochimie 89:770-778. doi: 10.1016/j.biochi.2007.02.009

Paula JR, Baptista M, Carvalho F, et al (2019) The past, present and future of cleaner fish cognitive performance as a function of CO 2 levels. Biol Lett 15:20190618. doi: 10.1098/rsbl.2019.0618

Pavlovich SS, Darling T, Hume AJ, et al (2020) Egyptian Rousette IFN-w Subtypes Elicit Distinct Antiviral Effects and Transcriptional Responses in Conspecific Cells. Front Immunol 11:435. doi:

10.3389/fimmu.2020.00435 
Pilla-Moffett D, Barber MF, Taylor GA, Coers J (2016) Interferon-Inducible GTPases in Host Resistance, Inflammation and Disease. J Mol Biol 428:3495-3513. doi: 10.1016/j.jmb.2016.04.032

Porteus CS, Hubbard PC, Uren Webster TM, et al (2018) Near-future CO2 levels impair the olfactory system of a marine fish. Nat Clim Chang 8:737-743. doi: 10.1038/s41558-018-0224-8

Porteus CS, Roggatz CC, Velez Z, et al (2021) Acidification can directly affect olfaction in marine organisms. J Exp Biol. doi: 10.1242/jeb.237941

Poynter SJ, DeWitte-Orr SJ (2016) Fish interferon-stimulated genes: The antiviral effectors. Dev Comp Immunol 65:218-225. doi: 10.1016/j.dci.2016.07.011

Quiniou SMA, Boudinot P, Bengtén E (2013) Comprehensive survey and genomic characterization of Tolllike receptors (TLRs) in channel catfish, Ictalurus punctatus: identification of novel fish TLRs. Immunogenetics 65:511-530. doi: 10.1007/s00251-013-0694-9

Ranjan P, Bowzard JB, Schwerzmann JW, et al (2009) Cytoplasmic nucleic acid sensors in antiviral immunity. Trends Mol Med 15:359-368. doi: 10.1016/j.molmed.2009.06.003

Riess M, Fuchs N V, Idica A, et al (2017) Interferons Induce Expression of SAMHD1 in Monocytes through Down-regulation of miR-181a and miR-30a. J Biol Chem 292:264-277. doi: 10.1074/jbc.M116.752584

Robertsen B (2006) The interferon system of teleost fish. Fish Shellfish Immunol 20:172-191. doi: 10.1016/j.fsi.2005.01.010

Rossi T, Nagelkerken I, Pistevos JCA, Connell SD (2016) Lost at sea: ocean acidification undermines larval fish orientation via altered hearing and marine soundscape modification. Biol Lett 12:20150937. doi: $10.1098 /$ rsbl.2015.0937

Schneider WM, Chevillotte MD, Rice CM (2014) Interferon-Stimulated Genes: A Complex Web of Host Defenses. Annu Rev Immunol 32:513-545. doi: 10.1146/annurev-immunol-032713-120231

Schunter C, Ravasi T, Munday PL, Nilsson GE (2019) Neural effects of elevated CO2 in fish may be amplified by a vicious cycle. Conserv Physiol. doi: 10.1093/conphys/coz100

Schunter C, Welch MJ, Nilsson GE, et al (2018) An interplay between plasticity and parental phenotype determines impacts of ocean acidification on a reef fish. Nat Ecol Evol 2:334-342. doi: 10.1038/s41559017-0428-8

Secombes CJ, Wang T, Bird S (2011) The interleukins of fish. Dev Comp Immunol 35:1336-1345. doi: https://doi.org/10.1016/j.dci.2011.05.001

Sepahi A, Kraus A, Casadei E, et al (2019) Olfactory sensory neurons mediate ultrarapid antiviral immune responses in a TrkA-dependent manner. Proc Natl Acad Sci U S A 116:12428-12436. doi: 
Servili A, Canario AVM, Mouchel O, Muñoz-Cueto JA (2020) Climate change impacts on fish reproduction are mediated at multiple levels of the brain-pituitary-gonad axis. Gen Comp Endocrinol 291:113439. doi: 10.1016/j.ygcen.2020.113439

Shiau CE, Monk KR, Joo W, Talbot WS (2013) An Anti-inflammatory NOD-like Receptor Is Required for Microglia Development. Cell Rep 5:1342-1352. doi: https://doi.org/10.1016/j.celrep.2013.11.004

Short KM, Cox TC (2006) Subclassification of the RBCC/TRIM superfamily reveals a novel motif necessary for microtubule binding. J Biol Chem 281:8970-8980. doi: 10.1074/jbc.M512755200

Stiasny MH, Mittermayer FH, Sswat M, et al (2016) Ocean Acidification Effects on Atlantic Cod Larval Survival and Recruitment to the Fished Population. PLoS One 11:e0155448. doi:

10.1371/journal.pone.0155448

Strickland J, Parsons A (1972) A Practical Handbook of Seawater Analysis. 293.

Su J, Yang C, Zhu Z, et al (2009) Enhanced grass carp reovirus resistance of Mx-transgenic rare minnow (Gobiocypris rarus). Fish Shellfish Immunol 26:828-835. doi: https://doi.org/10.1016/j.fsi.2008.12.007

Sun T, Tang X, Jiang Y, Wang Y (2017) Seawater acidification induced immune function changes of haemocytes in Mytilus edulis: a comparative study of CO2 and HCl enrichment. Sci Rep 7:41488. doi: $10.1038 /$ srep41488

Tacchi L, Musharrafieh R, Larragoite ET, et al (2014) Nasal immunity is an ancient arm of the mucosal immune system of vertebrates. Nat Commun. doi: 10.1038/ncomms6205

Takeuchi O, Akira S (2009) Innate immunity to virus infection. Immunol Rev 227:75-86. doi: 10.1111/j.1600-065X.2008.00737.x

Tangherlini M, Corinaldesi C, Ape F, et al (2021) Ocean Acidification Induces Changes in Virus-Host Relationships in Mediterranean Benthic Ecosystems. Microorganisms 9:769. doi: 10.3390/microorganisms 9040769

Tine M, Kuhl H, Gagnaire P-A, et al (2014) European sea bass genome and its variation provide insights into adaptation to euryhalinity and speciation. Nat Commun 5:5770. doi: 10.1038/ncomms6770

Traving SJ, Clokie MRJ, Middelboe M (2014) Increased acidification has a profound effect on the interactions between the cyanobacterium Synechococcus sp. WH7803 and its viruses. FEMS Microbiol Ecol 87:133-141. doi: 10.1111/1574-6941.12199

Tresguerres M, Hamilton TJ (2017) Acid-base physiology, neurobiology and behaviour in relation to CO2 induced ocean acidification. J Exp Biol 220:2136-2148. doi: 10.1242/jeb.144113 
Tsang HH, Welch MJ, Munday PL, et al (2020) Proteomic Responses to Ocean Acidification in the Brain of Juvenile Coral Reef Fish. Front Mar Sci 7:605. doi: 10.3389/fmars.2020.00605

Valero Y, Morcillo P, Meseguer J, et al (2015) Characterization of the IFN pathway in the teleost fish gonad against vertically transmitted viral nervous necrosis virus. J Gen Virol 96:2176-2187. doi:

10.1099/vir.0.000164

Vezzulli L, Colwell RR, Pruzzo C (2013) Ocean Warming and Spread of Pathogenic Vibrios in the Aquatic Environment. Microb Ecol 65:817-825. doi: 10.1007/s00248-012-0163-2

Wang Q, Cao R, Ning X, et al (2016) Effects of ocean acidification on immune responses of the Pacific oyster Crassostrea gigas. Fish Shellfish Immunol 49:24-33. doi: 10.1016/j.fsi.2015.12.025

Wang T, Kono T, Monte MM, et al (2013) Identification of IL-34 in teleost fish: differential expression of rainbow trout IL-34, MCSF1 and MCSF2, ligands of the MCSF receptor. Mol Immunol 53:398-409. doi: 10.1016/j.molimm.2012.09.008

Wang T, Yan B, Lou L, et al (2019) Nlrc3-like is required for microglia maintenance in zebrafish. J Genet Genomics 46:291-299. doi: 10.1016/j.jgg.2019.06.002

Wang W, Xu L, Su J, et al (2017) Transcriptional Regulation of Antiviral Interferon-Stimulated Genes. Trends Microbiol 25:573-584. doi: 10.1016/j.tim.2017.01.001

Wang X, Li C, Jia Z, et al (2021) Regulation of apoptosis by Pacific oyster Crassostrea gigas reveals acclimation strategy to $\mathrm{CO} 2$ driven acidification. Ecotoxicol Environ Saf 217:112235. doi: https://doi.org/10.1016/j.ecoenv.2021.112235

Williams CR, Dittman AH, McElhany P, et al (2019) Elevated CO 2 impairs olfactory-mediated neural and behavioral responses and gene expression in ocean-phase coho salmon (Oncorhynchus kisutch). Glob Chang Biol 25:963-977. doi: 10.1111/gcb.14532

Williamson P, Pörtner H, Widdicombe S, Gattuso J (2020) Ideas and Perspectives: When ocean acidification experiments are not the same, reproducibility is not tested. Biogeosciences Discuss 18:1-7. doi: $10.5194 / \mathrm{bg}-2020-394$

Wu Y-C, Lu Y-F, Chi S-C (2010) Anti-viral mechanism of barramundi Mx against betanodavirus involves the inhibition of viral RNA synthesis through the interference of RdRp. Fish Shellfish Immunol 28:467475. doi: 10.1016/j.fsi.2009.12.008

Yang G-J, Lu X-J, Chen Q, Chen J (2015) Molecular characterization and functional analysis of a novel Ctype lectin receptor-like gene from a teleost fish, Plecoglossus altivelis. Fish Shellfish Immunol 44:603610. doi: 10.1016/j.fsi.2015.03.037 
Zhang F, Shan S, Xu X, et al (2019) Molecular characterization and expression analysis of two peptidoglycan recognition proteins (CcPGRP5, CCPGRP6) in larvae ontogeny of common carp Cyprinus carpio L. and upon immune stimulation by bacteria. BMC Vet Res 15:10. doi: 10.1186/s12917-018-17441

\section{Figures}

Figure 1

Methodological summary. It is shown the rearing times and procedures applied on Dicentrarchus labrax parental linage (F0) and their offspring (F1) exposed to either the control (pH8.0) or the acidified (pH7.6) treatments; r: replica; nc: negative control.

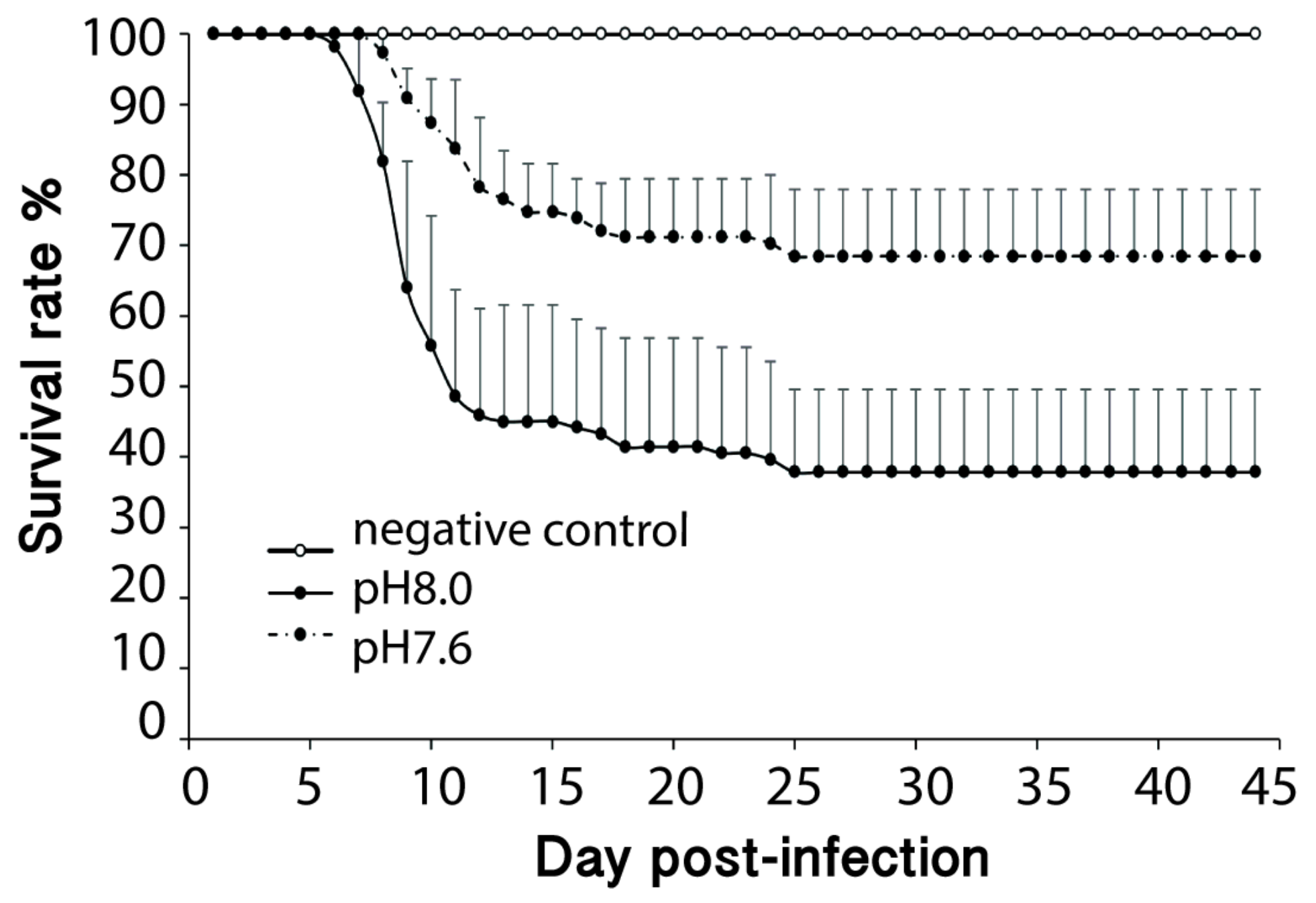

Figure 2 
Survival rate (\%) of F1 Dicentrarchus labrax after viral challenge. Curves indicate the survival rate of noninfected juveniles (white circle) and infected juveniles (black circle) with W80 strain either from the control treatment ( $\mathrm{pH} 8.0$, continuous line) or the acidified ( $\mathrm{pH} 7.6$, broken line) treatment. Each challenge was performed in triplicate with 37 fish per replica tank. Survival was monitored during 45 days postinfection.

\section{Figure 3}

Gene ontology enrichments for biological processes. Enriched (q-value $\leq 0.01$ ) biological processes related to the (A) up-regulated and (B) the down-regulated genes in F1 Dicentrarchus labrax exposed to ocean acidification.

Figure 4

Conceptual framework. The impacts of intergenerational ocean acidification (OA) on F1 Dicentrarchus labrax juveniles are shown for both the viral challenge and the ARN-Seq analysis

\section{Supplementary Files}

This is a list of supplementary files associated with this preprint. Click to download.

- additionalfiles.xlsx 